\title{
Evaluation of General English Coursebooks in Iranian Universities: A Critical Thinking Perspective
}

\author{
Maryam Azizi \\ Islamic Azad University, Shahreza Branch, Iran \\ Email: Azizi.maryam64@gmail.com \\ Mohammad Reza Talebinejad \\ Islamic Azad University, Shahreza Branch, Iran \\ Email: talebinejad@IAUSH.ac.ir; rtalebinezhad@yahoo.com
}

\begin{abstract}
The present study aimed at providing an evaluation of General English coursebooks used at universities in Iran. To this end, a retrospective evaluation was designed to examine the reading comprehension questions of a single sample of such coursebooks in terms of the degree to which they foster critical thinking. Each question was analyzed based on Facione's (2011) critical thinking model (consisting of 6 features); then, the data were analyzed and occurrence percentage of each feature was calculated. The results revealed the extent to which the coursebook matched the criteria in fostering critical thinking. Furthermore, the findings of the study seem to suggest that Iranian university students could not be expected to become critical thinkers through the study of such coursebooks.
\end{abstract}

Index Terms - textbook evaluation, comprehension questions, critical thinking, Fcion's (2011) critical thinking model

\section{INTRODUCTION}

Since the end of 1970s, there has been a change of focus from teachers to the learners. In line with this importance, a great need was felt to design all instructional materials in a way to elevate the students' thoughts. As Sheldon (1988, p.245) mentioned, "learners are not taught in a vacuum, but come from somewhere and are proceeding towards specific educational goals and future training". In order to achieve such goals, educational materials, particularly textbooks should be evaluated, because textbooks are the fundamental materials in the learning process. According to Hutchinson and Torres (1994), the textbook has a vital and positive role to play in teaching and the learning process. Litz (2005) holds that whether one believes textbooks are too inflexible and biased to be used directly as instructional material, there can be no denying that they are still the most valuable element in educational systems.

Sheldon (1988) believed textbooks are the visible heart of any ELT program for both teachers and students; however, as a matter of fact textbooks suffer from some shortcomings. Litz (2005) stated that one of the reasons for having undesired and unsatisfied ELT textbook is the fact that they are often regarded as the "tainted and product of an author's or a publisher's design for quick profit" (Sheldon, 1988, p.239), so such books present disjointed materials. Moreover, to Nation and Macalisten (2010), a coursebook evaluation searches for strengths and weaknesses but actually the weaknesses cause problem. Consequently, we should apply appropriate criteria to evaluate textbooks to identify their strengths and weaknesses and promote the merits and eliminate demerits. The essential issues for instructional material are the level of quality and appropriateness of the content of the textbooks. Allwright (1990) argued that materials should teach students to learn. Besides, he emphasized that materials control learning and teaching. In Iranian educational system students rely heavily on coursebooks and learn materials in a way that the coursebooks present them; therefore, the content of textbook is outbalance of anything else. O'Neill (1982) believed that great attention must be devoted to spontaneous, creative interaction in the classroom and textbook can help to do this. Despite the agreement with the basic attitude, the researcher in the present study believes that there must be also a creative interaction between learners and the content of coursebook. Whenever the creative interaction does not occurred, coursebooks are only dead pages (O’Neil, 1982).

From another viewpoint, the content of textbooks must train critical thinker students. Those who make good decisions and improve their own future are successful in education and are not dependent on the textbook. Therefore, the textbook must help to sharpen the students' critical thinking skills. There are different General English coursebooks used in Iranian universities, consisting of some reading passages followed by several reading comprehension questions. The university students read the texts to get ready for the special courses. Yet, unfortunately, the reading 
comprehension questions of the books do not match the students' level of proficiency. As a result, some learners neither need to comprehend the text nor to think to answer the questions.

Although currently teaching materials pay attention to the learner interests and tastes, this necessity does not prove fruitful by its own. As mentioned before, due to the vital role played by textbooks in language classrooms, the importance of preparing materials matching the desired features in the target situation demonstrates the significance of such studies. As well, they can help to reveal the weakness areas of the textbook in fostering critical thinking and investigate its cognitive aspects of questions. As far as the review of related studies indicates, critical thinking in the General English books in Iran has never been explicitly discussed. There is a serious lack of researches to examine the reading comprehension questions and their effects on students' thought. As Facione (2011) mentioned, "Failures of critical thinking contribute to job loss, gullible voters, bad decisions, unplanned pregnancies, family violence, divorce, drug addiction, academic failure" (P.3). In addition, Facione (2011) believed "there is a significant correlation between critical thinking and reading comprehension" (P.23). The mutual relationship between these two is further explained as well. Critical thinking is an essential factor to improve learners' thought and to make them successful in the next steps in their life. So, it is expected from curriculum designers or those who are involved in material preparation to place a high value on critical thinking.

Therefore, this study intended to investigate the extent to which certain designed questions have been prepared based on critical thinking model and to evaluate whether the textbook foster critical thinking or not. For this purpose, the content of a general English coursebook used at Iranian universities will be analyzed based on Facione's (2011) critical thinking model. Based on the results, the defects of coursebook will be discussed and some suggestions will be offered to improve these materials. Besides, due to the earlier mentioned caveats in disregarding a crucial position for critical thinking in the existing checklists, it seems that the present study would be helpful in opening a new horizon in the area of material evaluation. Hence, in the assessment process of comprehension questions in university English coursebooks, answers to the following research questions have been sought:

1) To what extent are features of Facione's (2011) critical thinking model represented in the coursebooks?

2) To what extent does each of the coursebooks foster critical thinking in their reading comprehension questions?

\section{BACKGROUND}

As a cognitive skill, most teachers believe in the importance of critical thinking for the students. The cognitive skills of synthesis, evaluation, inference and monitoring employed in the complex process of reading (Grabe, 1991, as cited in Celce-Murcia,2001) are those cognitive skills that Facione (2011) considers as being at the very core of critical thinking. It means that both critical thinking and reading have some cognitive abilities in common. In Iranian educational system, most of the students have not developed critical thinking skills while such skills will not develop by themselves and demand teaching. Yet, teaching critical thinking skills is a difficult and time consuming task. Students must learn to think critically and become self-confident as well as open-minded to achieve greater success in their work and get better positions in their education.

In relation to this field, a large number of studies have been done around the world, evaluating textbooks from various perspectives and some studies concerning critical thinking in reading in EFL contexts. These researches are divided into two categories of theoretical and practical. This section deals with some of these researches carried out in the context of Iran and in other countries all over the world.

Concerning the Iranian attempts, Yarmohammadi (2002) evaluated the senior high school textbooks in terms of Tucker's revised model. He concluded his study by mentioning some shortcomings such as, lack of authenticity, using English and Persian names interchangeably and ignorance of oral skills.

Rahimy (2007) evaluated a reading comprehension textbook for the university students entitling Reading Comprehension for the University Students, in Iran. Several schemes and checklists (e.g. Ansary and Babaii, 2002; Garinger, 2002; Harmer, 1998) were used which included features of content, layout, additional materials, unit grading, reading comprehension skills, etc.

Mirzaie (2008) studied the relationship between critical thinking and lexical inferencing of Iranian EFL learners. The scores showed that those who gained higher in critical thinking outperformed those with lower scores.

Pishghadam and Motkef (2008) analyzed two texts (taken from New Interchange series and high school English books). Their study was conducted with aim of making a connection between CDA, Critical Discourse Analysis, critical thinking, and ZPD, Zone of Proximal Development. The result of their study focusing on reading texts exhibited that most of the texts are laden with hidden ideologies and power relations and teachers are responsible to make students aware of these hidden ideas.

Azizifar, Koosha \& Lotfi (2010) carried out an evaluation of two series of ELT textbooks used for teaching English language in Iranian high schools from 1965 to the present. In this course of study, Tucker's (1975) textbook evaluation model was used. The results suggested that ELT textbooks were one of the fundamental factors in the learners' English language achievement.

Karamouzian (2010) analyzed the content of a reading comprehension series entitled Reading through Interaction used at the university level in Iran. A newly developed checklist was applied. Results of the study indicated that the overall quality of the three books was convenient, but there was a lack of materials on grammar and pronunciation. 
In another study, Kamili and Fahim (2011, pp. 104-111) investigated the relationships between critical thinking ability, resilience- a measure of successful stress-coping ability- and reading comprehension of texts containing unknown vocabulary items. The results indicated that "EFL learners' critical thinking levels have significant effects on their resilience levels. The study also revealed that "learners' critical thinking levels have significant effects on their reading comprehension ability when faced with unknown vocabulary items."

In addition to the above native studies, a number of similar studies in different contexts were conducted as well.

Tomlinson et al (2001) used a list of 133 course evaluation criteria to evaluate eight current adult courses published in the UK. The textbooks evaluated were Language in Use and True to Life by Cambridge University Press, Cutting Edge and Wavelength by Pearson Longman, Inside Out and Reward by Macmillan Heinemann Press. His checklist had two main parts of overall criteria and coursebook specific criteria.

McGrath (2002) reviewed a number of employed checklists and criteria in evaluating materials. He distinguished three main stages in evaluation as pre-use, in-use, and post-use evaluation. He also suggested some criteria for choosing a suitable method of evaluation.

Litz (2005) carried out a complex evaluation process of a textbook (English Firsthand 2) used in Sung Kyun Kwan University in Suwon, South Korea. The purpose of the study was to determine the overall pedagogical value and suitability of the book towards the specific language program.

Thein (2006) evaluated the effectiveness of the textbooks used for teaching English to religious studies students at Myanmar Institute of Technology. The study investigated the extent to which teachers' and learners' expectations matched the objectives of the program in developing the students' communicative skills and critical thinking.

Yujong (2011) examined an effort to effort to support critical literacy in English as a foreign language (EFL) setting by analyzing one college EFL reading classroom in which students read and responded to articles from "The New Yorker". Results show that when taught to be critical readers of the text, these EFL participants were able to actively use linguistic resources from the article as well as their own cultural and personal experience to support their ideas and raise questions.

To sum up, all the previous studies evaluated textbooks in relation to various factors with different topics. However, there are no studies evaluating Iranian university General English coursebooks from the critical thinking perspective.

\section{METHODOLOGY}

As a comparative-analytical study, the general English coursebooks used in Iranian universities were sampled for analysis. From among several such coursebooks, the one used at a very populated university in Iran was selected. The book consists of 4 major sections, each section divided into 3 to 4 units. The units include reading passages which are followed by several reading comprehension questions. Hence, each question and each unit is evaluated to see which features of Facion's (2011) critical thinking model are more emphasized and also to identify the frequency of occurrence of each feature. The specifications of the selected book are as follows:

Jalilifar, A., Abdollahzadeh, E., Mohmedi, F., \& Mir Tabatabai, M. (2009). English for University Students: An Orientation Course. Tehran: Parayab Publishing Company.

The content of the book is further outlined below:

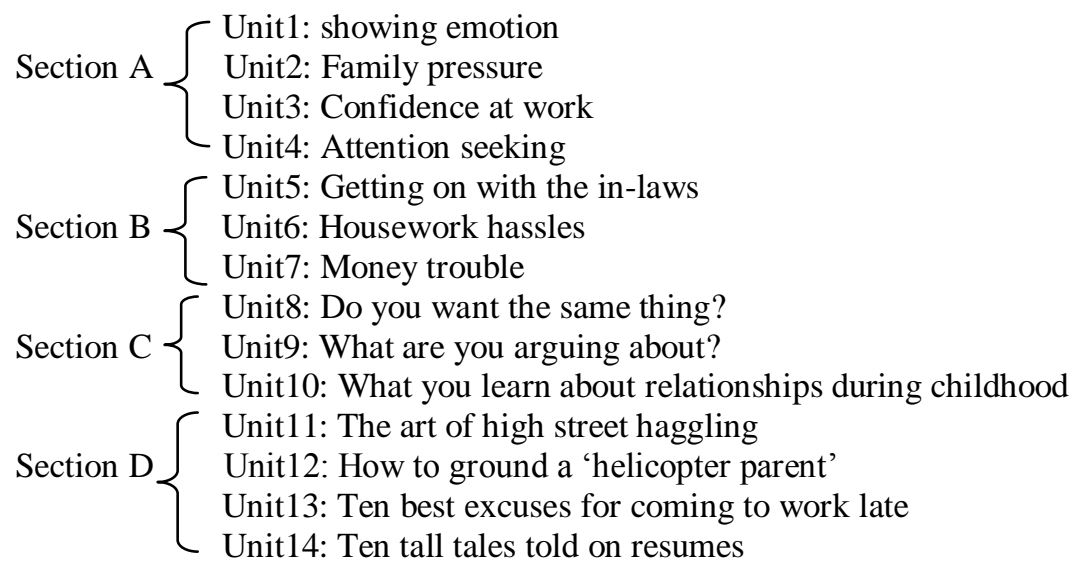

The instrument used to do the analysis was Facion's (2011) critical thinking model. This model consists of six cognitive skills: Interpretation, analysis, evaluation, inference, explanation, and self-regulation.
1. Interpretation
2. Analysis
3. Evaluation
4. Inference
5. Explanation
6. Self-regulation

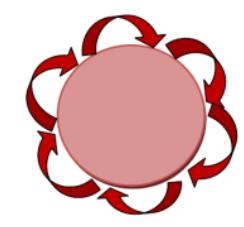

Facione (2011) has defined the cognitive skills as follows: 
- Interpretation: means comprehending the meaning of various questions, statements, judgments, and experiences.

- Analysis: is identifying the actual relationship among different information statements, questions, ideas, and experiences.

- Evaluation: is evaluating credibility of various opinions, questions, beliefs, etc.

- Inference: refers to the use of elements needed to form hypotheses and make logical conclusion.

- Explanation: is to be able to make a coherent result of others reasoning.

- Self-regulation: is conscious control and monitoring one's cognitive activities.

Therefore, based on the detailed accounts of the employed model, the data were collected through the analysis of reading comprehension questions of the selected General English coursebook. Although this study is a qualitative research, some quantitative records were also represented to give some inferential statistics for each feature of Facion's (2011) critical thinking model.

\section{FINDINGS}

This section mainly deals with the existence accounts of Facion's (2011) critical thinking features in separate questions as well as in each unit in terms of percentages. The findings are then compared to the optimal suggested accounts and will be subject to further detailed discussions in the next part. To have a clear view of question based accounts, the reader is referred to appendix I wherein the results are provided in further details. It's noteworthy to mention that, the optimal record in these tables refers to the cases where at least four features are present in all the questions. This condition provides the expected value of $66.6 \%$ for each unit.

Based on the results, only 4 out of 7 questions of the unit 1 had one or two features of the model and the rest had no features. Because of direct mentioning of the answers in the text, students did not need to think or to comprehend the text to provide answers. The representation of these features in unit one is about $16.6 \%$ while the optimal percentage for questions to be considered as critical thinking questions is $66.6 \%$. Clearly, there is a long distance between the obtained percentage of existed features and the optimal percentage.

In unit 2, only one out of 6 questions did not entail any critical thinking feature. Yet, the other five included at most two critical features which in turn, led to the total representation of $25 \%$ falling well below the optimal record.

Concerning the third unit, only three out of 6 questions favored the existence of at least one feature. This resulted in the total occurrence percentage of 16.67 which was highly distant from the expected optimal value of 66.6.

In relation to unit 4 , only three questions included merely the interpretation feature among the six suggested critical features. This led to the large difference between the actual occurrence of features (i.e. 8.3\%) and the expected value.

From the 5 designed questions in unit 5, two questions had at most two of the suggested critical features. The overall record of this inclusion (10\%) was again far from the optimal expected record.

The involved eight questions in unit 6 reported an inclusion of four questions with two critical thinking features of interpretation and explanation and one with only one interpretation feature. Despite the more frequent records, the total represented account (18.7\%) lagged behind the optimal suggested value (66.6\%).

Unit 7 included 6 questions out of which 2 had two critical features and one only one feature of interpretation. The total representation value of $13.8 \%$ was again highly different from the expected value.

Concerning the eighth unit, two out of nine questions included the two interpretation and explanation features. Besides, the first question employed the two evaluation and explanation features. The ninth question used the only interpretation feature. Although a number of features were employed in certain questions, the overall representation record of $12.9 \%$ was far from the expected value.

In relation to unit 9, out of 6 questions, the presence of two separate critical features was found in only two. This low feature representation resulted in the record of $5.5 \%$ which was greatly distant from the optimal value.

Regarding the tenth unit, only two questions out of 5 had employed the interpretation feature. Not surprisingly, the low total record of $6.6 \%$ was distant from the optimal value.

Similarly, in unit 11, merely two questions out of 6 recorded the presence of interpretation critical feature. Therefore, the overall representation value of 5.5 appeared as against the suggested optimal value.

With respect to the twelfth unit, only one out of 6 questions had employed the interpretation feature. Hence, this low representative value of $2.7 \%$ lagged far behind the optimal predicted value.

Concerning unit 13, out of 5 questions, one had the explanation and another had employed interpretation critical thinking features. The total representation value of $6.6 \%$ was again far from the optimal value.

Finally, in relation to the last unit, two out of 7 questions had employed the only interpretation feature. This low frequency resulted in the total value of $4.7 \%$ which was highly distant from the optimal expected record.

The following figure provides a clear graphic representation of the actual representation records of critical thinking features across each unit. 


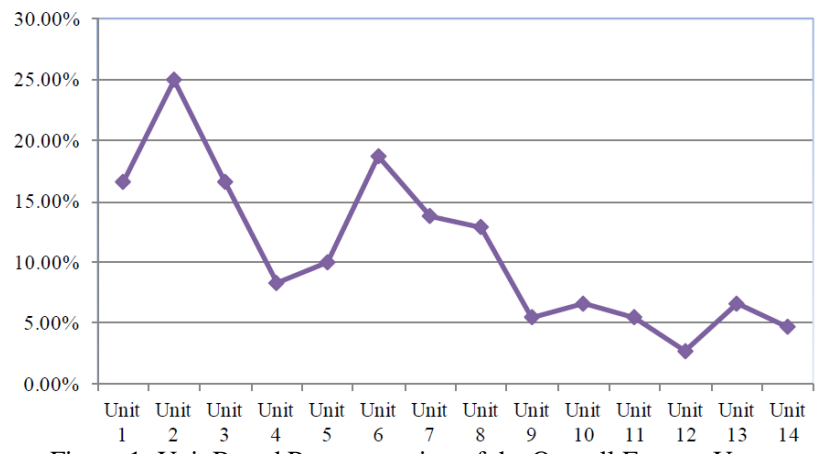

Figure 1. Unit Based Representation of the Overall Feature Usage

Accordingly, through the 14 examined units, the second unit followed by units 6 and 1 had employed the highest number of features. Meanwhile, unit 12 was regarded as the least representative of the critical thinking features.

Besides the above mentioned accounts, table 1 clearly represents another view of the employed critical thinking features in each unit.

TABLE 1.

UNIT BASED REPRESENTATION OF CRITICAL THINKING FEATURES

\begin{tabular}{|c|c|c|c|c|c|c|c|}
\hline & Interpretation & Analysis & Evaluation & Inference & Explanation & Self-regulation & Mean percentage \\
\hline Unit 1 & $4(9.52 \%)$ & & & & $3(7.14 \%)$ & & $16.6 \%$ \\
\hline Unit 2 & $5(13.8 \%)$ & & & & $4(11.1 \%)$ & & $25 \%$ \\
\hline Unit 3 & $3(8.3 \%)$ & & & $1(2.7 \%)$ & $2(5.5 \%)$ & & $16.6 \%$ \\
\hline Unit 5 & $2(6.6 \%)$ & & & & $1(3.3 \%)$ & & $10 \%$ \\
\hline Unit 6 & $5(10.4 \%)$ & & & & $4(8.3 \%)$ & & $18.7 \%$ \\
\hline Unit 7 & $2(5.5 \%)$ & $1(2.7 \%)$ & & & $2(5.5 \%)$ & & $13.8 \%$ \\
\hline Unit 9 & $1(2.7 \%)$ & & & & $1(2.7 \%)$ & & $5.5 \%$ \\
\hline Unit 10 & $2(6.6 \%)$ & & & & & & $6.6 \%$ \\
\hline Unit 11 & $2(5.5 \%)$ & & & & & & $5.5 \%$ \\
\hline Unit 12 & $1(2.7 \%)$ & & & & & & $2.7 \%$ \\
\hline Unit 13 & $1(3.3 \%)$ & & & & $1(3.3 \%)$ & & $6.6 \%$ \\
\hline Unit 14 & $2(4.7 \%)$ & & & & & & $4.7 \%$ \\
\hline
\end{tabular}

Following these records, there is a possibility to account for the highly frequent employed features in general and in particular units. Based on the findings, the highest frequent employed feature had been the interpretation feature which had been present in all the units with the highest record of $13.8 \%$ in unit 2 . Yet, after self-regulation with no occurrence of usage the least frequent feature had been analysis, evaluation and inference each with only one occurrence.

Finally, an overall account of the examined critical thinking features in the coursebook is presented.

TABLE 2.

REPRESENTATION OF EACH FEATURES OF FACION'S (2011) CRITICAL THINKING MODEL IN THE COURSEBOOK

\begin{tabular}{|l|c|c|c|}
\hline & Frequency & Percentage & Optimal percentage \\
\hline Interpretation & 36 & $10.2 \%$ & $25 \%$ \\
\hline Analysis & 1 & $0.28 \%$ & $25 \%$ \\
\hline Evaluation & 1 & $0.28 \%$ & $25 \%$ \\
\hline Inference & 1 & $0.28 \%$ & $25 \%$ \\
\hline Explanation & 21 & $6 \%$ & $25 \%$ \\
\hline Self-regulation & 0 & $0 \%$ & $25 \%$ \\
\hline
\end{tabular}

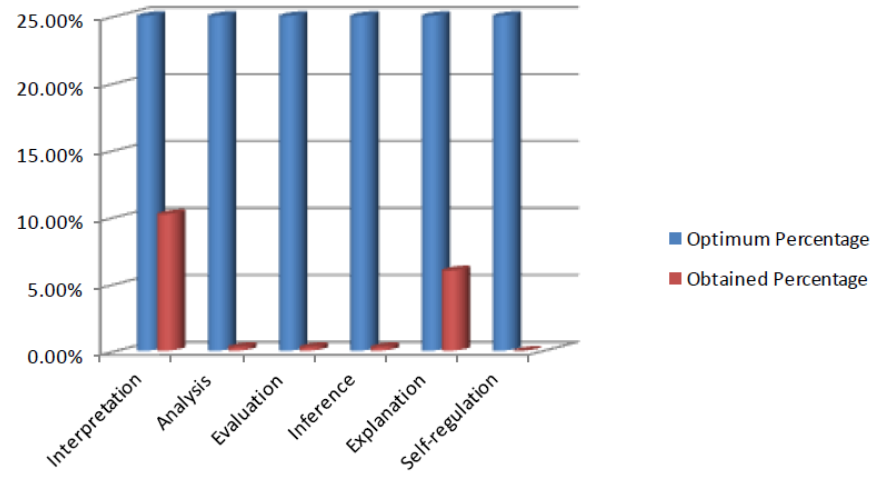




\section{Discussion}

The collected data made it clear that the units in the book did not appear homogeneous in their application of critical thinking features.

Regarding the first research question, the data showed that each unit of the book had a low percentage of Facion's (2011) critical thinking features, lower than the optimum percentage (66.6\%). 3of 6 features (Evaluation, Analysis, Inference) had 1 frequency in the entire book, one of the features (self-regulation) had no frequency and the rest (Interpretation \& Explanation) had higher frequencies in the book, the former with 36 frequency as the most frequent and the latter with 21 cases.

As to the second question, the occurrence of Facion's (2011) critical thinking features was too rare in the book. Therefore, this book and its reading comprehension questions neither fostered critical thinking nor examined the students' comprehension. Students may easily find the answer to the questions explicitly mentioned in the text. This proves crucial in the sense that, as they proceed to the end of the book (to the last units) reading comprehension questions became simpler and more primitive, while the logical and reasonable method suggests that questions become more complex step by step. Such questions are more similar to the display questions with their obvious answers which do not need any thinking.

Furthermore, in the process of evaluation it was found out that the reading comprehension questions of each unit had not entirely covered the text. Moreover, such questions were so ridiculous for university students with a certain level of proficiency.

Reading passages included comprehension questions at the end of each text. In order to have balanced multilevel questions, some low-level as well as high-level questions should be included. To foster critical thinking one needs some kinds of questions, like inference questions, analysis questions, logical reasoning questions, etc. Hereby, it is suggested to ask hierarchical questions with philosophical basis. The example may include cases like "is there any hidden and specific idea in the text? If yes, are you agree or disagree with it? If agree, why? If disagree, what is the reason?" and so on. Conclusively, this book could not be regarded as one which fosters critical thinking, even is not suitable for comprehension.

\section{CONCLUSION}

This article tried to analyze the reading comprehension questions presented in a General English coursebook used in the Iranian university based on Facion's (2011) critical thinking model to know which feature of the model was more emphasized. Although the book and its exercises were believed to have been designed to increase the students' comprehension, the features of the model were presented in very low frequencies. Therefore, this book neither increased the students' comprehension nor fostered their critical thinking.

\section{APPENDIX A}

TABLE1

REPRESENTATION OF FACION'S (2011) CRITICAL THINKING FEATURES IN UNIT 1

\begin{tabular}{|c|c|c|c|c|c|c|c|}
\hline Questions & Interpretation & Analysis & Evaluation & Inference & Explanation & Self-regulation & Percentage \\
\hline Q. 1 & $\sqrt{ }$ & & & & $\sqrt{ }$ & & $4.76 \%$ \\
\hline Q. 2 & & & & & & & $0 \%$ \\
\hline Q. 3 & & & & & & & $0 \%$ \\
\hline Q.4 & & & & & & & $0 \%$ \\
\hline Q.5 & $\sqrt{ }$ & & & & $\sqrt{ }$ & & $4.76 \%$ \\
\hline Q.6 & $\sqrt{ }$ & & & & $\sqrt{ }$ & & $4.76 \%$ \\
\hline Q.7 & $\sqrt{ }$ & & & & & & $2.38 \%$ \\
\hline Total & & & & & & & $16.6 \%$ \\
\hline Optimal & & & & & & & $66.6 \%$ \\
\hline
\end{tabular}

TABLE2.

REPRESENTATION OF FACION'S CRITICAL THINKING FEATURES IN UNIT 2

\begin{tabular}{|c|c|c|c|c|c|c|c|}
\hline Questions & Interpretation & Analysis & Evaluation & Inference & Explanation & Self-regulation & Percentage \\
\hline Q.1 & & & & & $\sqrt{ }$ & & $2.77 \%$ \\
\hline Q.2 & $\sqrt{ }$ & & & & $\sqrt{ }$ & & $5.55 \%$ \\
\hline Q.3 & $\sqrt{ }$ & & & & & & $2.77 \%$ \\
\hline Q.4 & $\sqrt{ }$ & & & & $\sqrt{ }$ & & $5.55 \%$ \\
\hline Q.5 & $\sqrt{ }$ & & & & $\sqrt{ }$ & & $5.55 \%$ \\
\hline Q.6 & $\sqrt{ }$ & & & & & & $2.77 \%$ \\
\hline Total & & & & & & & $25 \%$ \\
\hline Optimal & & & & & & & $66.6 \%$ \\
\hline
\end{tabular}


TABLE3.

REPRESENTATION OF FACION'S CRITICAL THINKING FEATURES IN UNIT 3

\begin{tabular}{|l|l|l|l|l|l|l|l|}
\hline Questions & Interpretation & Analysis & Evaluation & Inference & Explanation & Self-regulation & Percentage \\
\hline Q.1 & & & & & & & \\
\hline Q.2 & $\sqrt{ }$ & & & $\sqrt{ }$ & $\sqrt{ }$ & \\
\hline Q.3 & $\sqrt{ }$ & & & & $\sqrt{ }$ & \\
\hline Q.4 & & & & & & & $5.33 \%$ \\
\hline Q.5 & & & & & & & $0 \%$ \\
\hline Q.6 & $\sqrt{ }$ & & & & & & $0 \%$ \\
\hline Total & & & & & & & $2.78 \%$ \\
\hline Optimal & & & & & & & $16.67 \%$ \\
\hline
\end{tabular}

TABLE4.

REPRESENTATION OF FACION'S CRITICAL THINKING FEATURES IN UNIT 4

\begin{tabular}{|c|c|c|c|c|c|c|c|}
\hline Questions & Interpretation & Analysis & Evaluation & Inference & Explanation & Self-regulation & Percentage \\
\hline Q.1 & $\sqrt{ }$ & & & & & & $2.77 \%$ \\
\hline Q.2 & & & & & & & $0 \%$ \\
\hline Q.3 & & & & & & & $0 \%$ \\
\hline Q.4 & & & & & & & $0 \%$ \\
\hline Q.5 & $\sqrt{ }$ & & & & & & $2.77 \%$ \\
\hline Q.6 & $\sqrt{ }$ & & & & & & $2.77 \%$ \\
\hline Total & & & & & & & $8.3 \%$ \\
\hline Optimal & & & & & & & $66.6 \%$ \\
\hline
\end{tabular}

TABLE5.

REPRESENTATION OF FACION'S CRITICAL THINKING FEATURES IN UNIT 5

\begin{tabular}{|l|l|l|l|l|l|l|l|}
\hline Questions & Interpretation & Analysis & Evaluation & Inference & Explanation & Self-regulation & Percentage \\
\hline Q.1 & & & & & & & $0 \%$ \\
\hline Q.2 & & & & & & & \\
\hline Q.3 & & & & & & & $0 \%$ \\
\hline Q.4 & $\sqrt{ }$ & & & & & & \\
\hline Q.5 & $\sqrt{ }$ & & & & & & \\
\hline Total & & & & & & & \\
\hline Optimal & & & & & & & \\
\hline
\end{tabular}

TABLE6.

REPRESENTATION OF FACION'S CRITICAL THINKING FEATURES IN UNIT 6

\begin{tabular}{|c|c|c|c|c|c|c|c|}
\hline Questions & Interpretation & Analysis & Evaluation & Inference & Explanation & Self-regulation & Percentage \\
\hline Q.1 & & & & & & & $0 \%$ \\
\hline Q.2 & $\sqrt{ }$ & & & & $\sqrt{ }$ & & $4.16 \%$ \\
\hline Q.3 & & & & & & & $0 \%$ \\
\hline Q.4 & & & & & & & $0 \%$ \\
\hline Q.5 & $\sqrt{ }$ & & & & $\sqrt{ }$ & & $4.16 \%$ \\
\hline Q.6 & $\sqrt{ }$ & & & & $\sqrt{ }$ & & $4.16 \%$ \\
\hline Q.7 & $\sqrt{ }$ & & & & $\sqrt{ }$ & & $4.16 \%$ \\
\hline Q.8 & $\sqrt{ }$ & & & & & & $2.08 \%$ \\
\hline Total & & & & & & & $18.7 \%$ \\
\hline Optimal & & & & & & & $66.6 \%$ \\
\hline
\end{tabular}

TABLE7.

REPRESENTATION OF FACION'S CRITICAL THINKING FEATURES IN UNIT 7

\begin{tabular}{|c|c|c|c|c|c|c|c|}
\hline Questions & Interpretation & Analysis & Evaluation & Inference & Explanation & Self-regulation & Percentage \\
\hline Q.1 & & & & & & & $0 \%$ \\
\hline Q.2 & & & & & & & $0 \%$ \\
\hline Q.3 & & & & & & & $0 \%$ \\
\hline Q.4 & $\sqrt{ }$ & & & & $\sqrt{ }$ & & $5.55 \%$ \\
\hline Q.5 & & $\sqrt{ }$ & & & $\sqrt{ }$ & & $5.55 \%$ \\
\hline Q.6 & $\sqrt{ }$ & & & & & & $2.78 \%$ \\
\hline Total & & & & & & & $13.8 \%$ \\
\hline Optimal & & & & & & & $66.6 \%$ \\
\hline
\end{tabular}


TABLE8.

REPRESENTATION OF FACION'S CRITICAL THINKING FEATURES IN UNIT 8

\begin{tabular}{|c|c|c|c|c|c|c|c|}
\hline Questions & Interpretation & Analysis & Evaluation & Inference & Explanation & Self-regulation & Percentage \\
\hline Q.1 & & & $\sqrt{ }$ & & $\sqrt{ }$ & & $3.7 \%$ \\
\hline Q.2 & & & & & & & $0 \%$ \\
\hline Q.3 & $\sqrt{ }$ & & & & $\sqrt{ }$ & & $3.7 \%$ \\
\hline Q.4 & & & & & & & $0 \%$ \\
\hline Q.5 & & & & & & & $0 \%$ \\
\hline Q.6 & & & & & & & $0 \%$ \\
\hline Q.7 & $\sqrt{ }$ & & & & $\sqrt{ }$ & & $3.7 \%$ \\
\hline Q.8 & & & & & & & $0 \%$ \\
\hline Q.9 & $\sqrt{ }$ & & & & & & $1.85 \%$ \\
\hline Total & & & & & & & $12.9 \%$ \\
\hline Optimal & & & & & & & $66.6 \%$ \\
\hline
\end{tabular}

TABLE9.

REPRESENTATION OF FACION'S CRITICAL THINKING FEATURES IN UNIT 9

\begin{tabular}{|c|c|c|c|c|c|c|c|}
\hline Questions & Interpretation & Analysis & Evaluation & Inference & Explanation & Self-regulation & Percentage \\
\hline Q.1 & & & & & & & $0 \%$ \\
\hline Q.2 & & & & & & & $0 \%$ \\
\hline Q.3 & & & & & $\sqrt{ }$ & & $2.77 \%$ \\
\hline Q.4 & & & & & & & $0 \%$ \\
\hline Q.5 & & & & & & & $0 \%$ \\
\hline Q.6 & $\sqrt{ }$ & & & & & & $2.77 \%$ \\
\hline Total & & & & & & & $5.5 \%$ \\
\hline Optimal & & & & & & & $66.6 \%$ \\
\hline
\end{tabular}

TABLE10.

REPRESENTATION OF FACION'S CRITICAL THINKING FEATURES IN UNIT 10

\begin{tabular}{|l|l|l|l|l|l|l|l|}
\hline Questions & Interpretation & Analysis & Evaluation & Inference & Explanation & Self-regulation & Percentage \\
\hline Q.1 & $\sqrt{ }$ & & & & & & $3.33 \%$ \\
\hline Q.2 & & & & & & & \\
\hline Q.3 & & & & & & & $0 \%$ \\
\hline Q.4 & & & & & & & $0 \%$ \\
\hline Q.5 & $\sqrt{ }$ & & & & & & \\
\hline Total & & & & & & & 0 \\
\hline Optimal & & & & & & & \\
\hline
\end{tabular}

TABLE11.

REPRESENTATION OF FACION'S CRITICAL THINKING FEATURES IN UNIT 11

\begin{tabular}{|l|l|l|l|l|l|l|l|}
\hline Questions & Interpretation & Analysis & Evaluation & Inference & Explanation & Self-regulation & Percentage \\
\hline Q.1 & & & & & & & $0 \%$ \\
\hline Q.2 & $\sqrt{ }$ & & & & & & \\
\hline Q.3 & & & & & & & \\
\hline Q.4 & & & & & & & \\
\hline Q.5 & & & & & & & $0 \%$ \\
\hline Q.6 & & & & & & & $0 \%$ \\
\hline Total & & & & & & & \\
\hline Optimal & & & & & & & \\
\hline
\end{tabular}

TABLE12.

REPRESENTATION OF FACION'S CRITICAL THINKING FEATURES IN UNIT 12

\begin{tabular}{|c|c|c|c|c|c|c|c|}
\hline Questions & Interpretation & Analysis & Evaluation & Inference & Explanation & Self-regulation & Percentage \\
\hline Q.1 & & & & & & & $0 \%$ \\
\hline Q.2 & & & & & & & $0 \%$ \\
\hline Q.3 & & & & & & & $0 \%$ \\
\hline Q.4 & & & & & & & $0 \%$ \\
\hline Q.5 & & & & & & & $0 \%$ \\
\hline Q.6 & $\sqrt{ }$ & & & & & & $2.7 \%$ \\
\hline Total & & & & & & & $2.7 \%$ \\
\hline Optimal & & & & & & & $66.6 \%$ \\
\hline
\end{tabular}

TABLE13.

REPRESENTATION OF FACION'S CRITICAL THINKING FEATURES IN UNIT 13

\begin{tabular}{|c|c|c|c|c|c|c|c|}
\hline Questions & Interpretation & Analysis & Evaluation & Inference & Explanation & Self-regulation & Percentage \\
\hline Q.1 & & & & & $\sqrt{ }$ & & $3.33 \%$ \\
\hline Q.2 & & & & & & & $0 \%$ \\
\hline Q.3 & & & & & & & $0 \%$ \\
\hline Q.4 & & & & & & & $0 \%$ \\
\hline Q.5 & $\sqrt{ }$ & & & & & & $3.33 \%$ \\
\hline Total & & & & & & & $6.6 \%$ \\
\hline Optimal & & & & & & & $66.6 \%$ \\
\hline
\end{tabular}


TABLE14.

REPRESENTATION OF FACION'S CRITICAL THINKING FEATURES IN UNIT 14

\begin{tabular}{|l|l|l|l|l|l|l|l|}
\hline Questions & Interpretation & Analysis & Evaluation & Inference & Explanation & Self-regulation & Percentage \\
\hline Q.1 & & & & & & \\
\hline Q.2 & & & & & & \\
\hline Q.3 & $\sqrt{ }$ & & & & & & \\
\hline Q.4 & & & & & & & \\
\hline Q.5 & & & & & & & \\
\hline Q.6 & & & & & & & \\
\hline Q.7 & $\sqrt{ }$ & & & & & & \\
\hline Total & & & & & & & \\
\hline Optimal & & & & & & & \\
\hline
\end{tabular}

\section{REFERENCES}

[1] Allwright, R. L. (1990). What do we want teaching materials for? In R. Rossner and R. Bolitho, (Eds.), Currents in language teaching. Oxford: Oxford University Press.

[2] Ansary, H., \& Babaii, E. (2002). Universal characteristics of EFL/ESL textbook: A step towards systematic textbook evaluation. The Internet TESL Journal, 2, 1-8.

[3] Azizifara, A., Kooshaa, M., Lotfia, A. R. (2010). An analytical evaluation of Iranian high school ELT textbooks from 1970 to the present. Procedia Social and Behavioral Sciences, Published by Elsevier Ltd. 3, 336-44

[4] CarrelL P. L. (1984). 'Schema theory and ESL reading: classroom implications and applications.' Modem Language Journal, 68/4:332-43.

[5] Celce-Murcia, M. (2001). Teaching English as a second or foreign language, ( $3^{\text {rd }}$ ed.). Boston, MA: Heinle \& Heinle.

[6] Eriksoussy., Zubaidah, M. (1993). Evaluating the English Language Textbook Studied at the First Year Intermediate Schools in Saudi Arabia. Unpublished MA thesis, King Saud University. Riyadh, Saudi Arabia.

[7] Facione, Peter, A. (2011). critical thinking: What it is and why it counts. Insight Assessment. Measured Reasons and The California Academic Press, Millbrae, CA.

[8] Garinger, D. (2002). Textbook selection for the ESL classroom. Center for Applied Linguistics Digest. Retrieved from: http://www.cal.org/resources/Digest/0210garinger.html.

[9] Grab, W.(1991). Current Development in second Language Reading Research. TESOL Quarterly, 25 (3), 375-406.

[10] Harmer, J. (1998). How to teach English: an introduction to the practice of English language teaching. Harlow, UK: Longman.

[11] Hutchinson, T. and E. Torres. (1994). 'The Textbook as Agent of Change'. ELT Journal. Volume 48/4, 315-328.

[12] Jahangard, A. (2008). Evaluation of the EFL Materials Taught at Iranian High Schools. Iranian EFL Journal, 1 (1), 31-49.

[13] Kamali, Z., \& Fahim, M. (2011). The Relationship between Critical Thinking Ability of Iranian EFL Learners and Their Resilience Level Facing Unfamiliar Vocabulary Items In reading. Journal of Language Teaching and Research, 2 (1), 104-111

[14] Karamoozian, F. M., and Riazi, A. M. (2008). Development of a new checklist for evaluating reading comprehension textbooks. ESP World, 7(3). Retrieved from:

[15] Litz, D. R. A. (2005). Textbook evaluation and ELT management: a South Korean 46 Iranian EFL Journal case study. Asian EFL Journal. Retrieved from: http://www.asian-efl-journal.com/Litz_thesis.pdf

[16] McGrath, I. (2002). Materials Evaluation and Design for Language Teaching. Edinburgh: Edinburgh University Press.

[17] Mirzai, Z. (2008). The Relationship between Critical Thinking and Lexical Inferencing of Iranian EFL Learners, Unpublished Master Thesis, Tehran, Iran: Islamic Azad University of Science and Research Campus.

[18] Nation, I.S.P., \& Macalister, J. (2010). Language curriculum Design. New York and London: Routledge.

[19] O'Neill, R. (1982). Why use textbooks? ELT Journal, 36, 104-111.

[20] Pishghadam, R., \& Motakef, R. (2008). CDA, Critical Thinking, and ZPD: A Comparative Study. Iran: Language Teaching Conference.

[21] Rahimy, R. (2007). A coursebook evaluation. ESP World, 6(2). Retrieved from: http://www.espworld.info/Articles_15/Textbook_Evaluation.htm

[22] Sheldon, L. (1988). Evaluating ELT textbooks and materials. English Language Teaching Journal, 42(4), 237-246.

[23] Thein, N. (2006). Evaluating the suitability and effectiveness of three English coursebooks at Myanmar Institute of Technology. Unpublished MA thesis, University of Thailand. Thailand.

[24] Tomlinson, B. et al. (2001). ELT Courses for Adults. ELT Journal, 55(1) 80-101.

[25] Tucker, C. A. (1975). Evaluating beginning textbooks. English Teaching Forum. 13, 355- 361.

[26] Williams, D. (1983). Developing criteria for textbook evaluation. ELT Journal, 37(2), 251- 255.

[27] Yarmohammadi, L. (2002). The evaluation of pre-university textbooks. The Newsletter of the Iranian Academy of Science, 18, 70-87.

[28] Yujung, P. (2011). Using New Articles to Build a Critical Literacy Classroom in an EFL setting. TESOL Journal, 2 (1), $24-51$. 


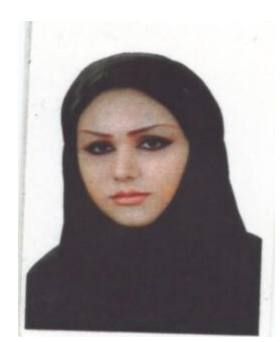

Maryam Azizi graduated from Sheikh Bahaie university, Isfahan, Iran, with a BA in English Translation in 2007. Maryam Azizi is an MA candidate in Graduate School of the Islamic Azad University, Shahreza Branch. She has presented one article in local conference. She is teaching English In different English Institutes. She has translated some books. Her areas of interest include sociolinguistic, cultural differences and critical thinking.

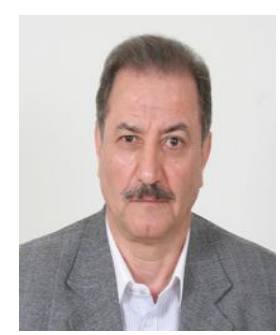

Mohammad Reza Talebinejad is an Associate Professor of Applied Linguistics at Islamic Azad University,Shahreza Branch. He is also an associate faculty member at Sheikhbahaee University, Iran. Dr Talebinejad received his BA in English Language and Literature, University of Isfahan in 1975. He then got his MA in TEFL from the University of Texas at Austin, USA in 1977. For his doctoral degree, Dr Talebinejad was admitted to the University of Sheffield, UK, where he did his $\mathrm{PhD}$ in Applied Linguistics in 1994.

He has widely published in Iranian as well as International professional journals such as Metaphor and Symbol, English Teaching Forum, Language Testing, IJAl, Language and Translation, Journal of Social Sciences, The International Journal of Humanities, and other local and international journals. Dr Talebinejad has presented papers in International conferences such as AILA, 2000; Atiner, 2011; RAAM, 2002, 2001 in Paris and Tunis, EUROSLA, Switzerland, 2006; Multicultural Conference, 2007, China. In addition, Dr Talebinejad has authored/coauthored eight books in related fields and ESP. 